\title{
ZABILJEŽBE PRAVNIH ČINJENICA U OVRŠNOM ZAKONU
}

Doc. dr. sc. Dinka Šago*

\author{
UDK: 347.952(497.5) \\ https://doi.org/10.30925/zpfsr.40.1.14 \\ Ur.: 14. siječnja 2019. \\ Pr.: 2. veljače 2019. \\ Prethodno priopćenje
}

\begin{abstract}
Sažetak
Tema je ovog rada zabilježba u službi zaštite povjerenja u zemljišne knjige s posebnim osvrtom na zabilježbe predviđene ovršnim pravilima i pravilima osiguranja. Zabilježbe koje su povezane sa ovršnim postupkom ne moraju biti vezane isključivo za Ovršni zakon. Zabilježba pokretanja postupka popunjava određenu prazninu koja se javlja u vremenu od podnošenja prijedloga za pokretanje ovršnog postupka i zabilježbe ovrhe. Zabilježba ovrhe prva je od zabilježbi koje se vežu za ovršni postupak. Razrađeni su učinci zabilježbe ovrhe koja je bitna radi očuvanja prava ovrhovoditelja, odnosno mogućnosti namirenja ovrhovoditelja, a tako i publiciranja kako je za određenu nekretninu u tijeku ovršni postupak. Zabilježba ovršivosti također je jedna od zabilježbi predviđenih Ovršnim zakonom. Njome se štiti ovrhovoditelj, odnosno predlagatelj osiguranja nakon dospijeća tražbine. U okviru zabilježbe ovršivosti obrađen je $i$ institut prisilnog zasnivanja založnog prava na nekretnini radi osiguranja tražbine.
\end{abstract}

Ključne riječi: zabilježba; zemljišne knjige; Ovršni zakon.

\section{1. $U V O D$}

Zabilježbom se u zemljišne knjige upisuju osobni odnosi nositelja knjižnih prava i pravne činjenice mjerodavne za pravni promet nekretnina. Zakonom o zemljišnim knjigama (dalje: ZZK) ${ }^{1}$ propisano je da se u zemljišnu knjigu upisuju određene pravne činjenice nastale tijekom zemljišnoknjižnoga postupka. Zabilježba i brisanje zabilježbe pravnih činjenica provodi se po službenoj dužnosti. Po službenoj se dužnosti zabilježuje da prijedlogu nije priložen izvornik isprave (čl. 103. st. 5. ZZK-a), da nije priložen ovjereni prijepis isprave sastavljene na stranom jeziku (čl. 104. st. 2. ZZK-a), da je odbijen prijedlog za upis (čl. 111. st. 1., 2. ZZK-a), brojevi istodobno zaprimljenih prijedloga za upis koji se odnose na isto zemljišnoknjižno

* Dr. sc. Dinka Šago, docentica, Pravni fakultet Sveučilišta u Splitu; dinka.sago@pravri.hr.

1 Zakon o zemljišnim knjigama, Narodne novine, br. 91/96., 68/98., 137/99 - Odluka Ustavnog suda broj U-I-58/1997., U-I-235/1997., U-I-237/1997., U-I-1053/1997., U-I-1054/1997. od 17. studenoga 1999., 114/01., 100/04., 107/07., 152/08. i 126/10., 55/13., 60/13, 108/17. 
tijelo (čl. 114. ZZK-a), da je pokrenut postupak za ispravljanje pogrješnog upisa (čl. 119. ZZK-a), rješenje suda prvog stupnja o odbacivanju žalbe (čl. 126. st. 1. ZZK-a), da je podnesena žalba protiv rješenja o upisu (čl. 127. st. 1. ZZK-a), naznake o glavnom i sporednim ulošcima u kojima je upisana zajednička hipoteka (čl. 130. st. 4. ZZK-a), da je djelomice ili potpuno brisana zajednička hipoteka u određenom ulošku (čl. 136. st. 2. ZZK-a), da je pokrenut postupak otpisa (čl. 161. st. 2. ZZK-a), da je podnesen prigovor protiv besteretnog otpisa dijelova male vrijednosti (čl. 157. st. 2. ZZK-a) te prijave i prigovori protiv upisa provedenih u postupku osnivanja zemljišne knjige (čl. 188. st. 3. ZZK-a). ${ }^{2}$

Zabilježbe pravnih činjenica po ZZK - a su: 1. zabilježba prvenstvenog reda; ${ }^{3}$ 2. zabilježba otkaza hipotekarne tražbine i tužbe; 3 . zabilježba spora; ${ }^{4} 4$. zabilježba tužbe radi pobijanja dužnikovih pravnih radnji; 5 . zabilježba imenovanja, opoziva ili promjene upravitelja; 6 . zabilježba odbijanja ovrhe te 7 . zabilježba dosude.

Zabilježbe pravnih činjenica po Zakonu o vlasništvu i drugim stvarnim pravima ${ }^{5}$ su: 1. zabilježba da su strojevi i slični uređaji koji služe nekretnini samostalne stvari; 2. zabilježba zabrane otuđenja i/ili opterećenja određene na temelju pravnog posla; ${ }^{6}$ 3. zabilježba ograničenja prava na razvrgnuće suvlasništva; 4. zabilježba načina upravljanja nekretninom; 5. zabilježba ograničenja prava suvlasnika na davanje u zakup ili najam posebnog dijela nekretnine; 6 . zabilježba o ključu raspodjele troškova cijele nekretnine i doprinosa zajedničkoj pričuvi; 7. zabilježba otkaza hipotekarne tražbine i tužbe; 8 . zabilježba obveze brisanja hipoteke te 9 . zabilježba pridržaja prvenstvenog reda.

Zabilježbe pravnih činjenica po Ovršnom zakonu su: ${ }^{7} 1$. zabilježba ovrhe; 2. zabilježba ovršivosti tražbine osigurane hipotekom te 3 . zabilježba privremene mjere osiguranja zabranom otuđenja ili opterećenja nekretnine.

Zabilježbe pravnih činjenica u drugim propisima su: 1. zabilježba ugovora o doživotnom uzdržavanju; 2. zabilježba postupka izvlaštenja; 3. zabilježba da za građevinu nisu priložene uporabna i građevna dozvola te 4 . zabilježba da je nekretnina

2 Tako Josipović, T., Zemljišnoknjižno pravo, Zagreb, Informator, 2001., str. 222.

3 Više kod Šago, D., Zabilježba prvenstvenog reda u zemljišnim knjigama, Zbornik radova s III. međunarodnog savjetovanja „Aktualnosti građanskog procesnog prava - nacionalna i usporedna pravnoteorijska i praktična dostignuća“, ur. Šago, D. i dr., Split, Sveučilište u Splitu, Pravni fakultet, 2017., str. 275-297.

4 Opširnije Šago, D., Provedba i učinci zabilježbe spora u zemljišnim knjigama u zakonodavstvu Republike Hrvatske, Revija za pravo i ekonomiju, Mostar, god. 18., 1/2017., str. 163-182.

5 Zakon o vlasništvu i drugim stvarnim pravima, Narodne novine, br. 91/96, 68/98 - Zakon o izmjenama i dopunama Zakona o prodaji stanova na kojima postoji stanarsko pravo (ukida čl. 371.), 137/99 - Odluka Ustavnog suda broj U-I-58/1997., U-I-235/1997., U-I-237/1997., U-I1053/1997., U-I-1054/1997. od 17. studenoga 1999., 22/00 - Odluka Ustavnog suda RH broj U-I-1094/1999. od 9. veljače 2000., 73/00, 129/00 - Zakon o izmjenama i dopunama Stečajnog zakona (u odnosu na čl. 366.-373.), 114/01, 79/06, 141/06, 146/08, 38/09, 153/09, 143/12, 152/14, 81/15 - pročišćeni tekst, 94/2017.

6 Opširnije Ernst, H., Zabilježba zabrane otuđenja ili opterećenja nekretnine na temelju pravnog posla, Aktualnosti hrvatskog zakonodavstva i pravne prakse, Godišnjak 11, 2004., str. 403-416.

7 Ovršni zakon, Narodne novine, br. 112/12, 25/13, 93/14, 55/16, 73/17. 
kulturno dobro. ${ }^{8}$

U nastavku rada osvrnut ćemo se na zabilježbe pravnih činjenica propisane odredbama OZ-a.

\section{ZABILJEŽBA OVRHE}

\subsection{Pojam}

Zemljišne knjige imaju važnu ulogu u stjecanju prava na nekretninama koja se osnivaju u postupku ovrhe ili osiguranja na nekretninama, za publiciranje različitih stvarnih i obveznih prava i pravnih činjenica važnih za pravno stanje nekretnine na kojoj se vodi postupak ovrhe ili osiguranja. OZ sadrži brojne odredbe koje u cijelosti odgovaraju određenim pravilima i načelima iz ZZK-a, kao što su npr. odredbe o nekretnini kao predmetu ovrhe, odredbe o knjižnom predniku i sl. ${ }^{9} \mathrm{U}$ ovršnom postupku sud određuje ovrhu onim sredstvom i na onim predmetima koji su navedeni u ovršnom prijedlogu. Čim donese rješenje o ovrsi, sud će po službenoj dužnosti zatražiti da se u zemljišnoj knjizi upiše zabilježba ovrhe (čl. 84. st. 1. OZ). Rješenje o ovrsi na nekretnini treba sadržavati i dio kojim se određuje zabilježba ovrhe na nekretnini koja je predmet ovrhe s tim da je sud dužan po službenoj dužnosti, na temelju ovršne isprave prije pravomoćnosti rješenja o ovrsi, a na temelju vjerodostojne isprave nakon pravomoćnosti rješenja o ovrsi, zatražiti da se u zemljišnoj knjizi upiše zabilježba ovrhe (čl. 84. st. 1. OZ). ${ }^{10}$ Zabilježba ovrhe ne može se odrediti na temelju rješenja o ovrsi javnog bilježnika kojim je određena ovrha na novčanoj tražbini po računu ovršenika. ${ }^{11}$

Zabilježba ovrhe prva je od zabilježbi koje se vežu uz ovršni postupak. Ovrha na nekretnini provodi se zabilježbom ovrhe u zemljišnoj knjizi, utvrđenjem njene vrijednosti, njenom prodajom te namirenjem ovrhovoditelja iz iznosa dobivenog prodajom nekretnine. Dakle, zabilježba ovrhe na nekretnini u ovršnom postupku je sredstvo ovrhe (čl. 80. OZ). Bitan sastavni dio rješenja o ovrsi na nekretnini je

8 Opširnije Čizmić, J., Šago, D., Kačer, B., Osnove zemljišnoknjižnog prava, Maribor, University of Maribor Press, 2018., str. 430-433.

9 Vidi Josipović, T., Uloga zemljišnih knjiga u pravnom prometu nekretnina, HGK, Sektor za trgovinu, Šesti forum hrvatskih posrednika u prometu nekretninama, www.agenti.hr, str. 53.

10 Jedna od najčešćih zabilježba u zemljišnoj knjizi je zabilježba ovrhe, pri čemu se najčešće u tim predmetima izjavljuje žalba u zemljišnoknjižnom postupku, a ne u ovršnom postupku. Više Barjaktar, B., Dopuštenost žalbe protiv rješenja zemljišnoknjižnog suda o upisu zabilježbe ovrhe, Informator, br. 5377, 2005., str. 8-13.

11 U tom smislu presuđeno: „Prema tome, zabilježbu ovrhe u smislu odredbe čl. 84. st. 1. OZ-a određuje isključivo ovršni sud i to po službenoj dužnosti čim donese rješenje o ovrsi na nekretnini. Prijedlog za upis zabilježbe ovrhe predlagatelj temelji na rješenju o ovrsi javnog bilježnika kojim je određena ovrha na novčanoj tražbini po računima ovršenika (protustranke) i na temelju takvog pravomoćnog i ovršnog rješenja o ovrsi predlagatelj može zatražiti od nadležnog suda da odredi ovrhu na predmetu ovrhe na kojem se na temelju takvog rješenja ne može tražiti izvansudska ovrha, a pretpostavka za podnošenje takvog prijedloga je bezuspješna provedba izvansudske ovrhe. O prijedlogu sud odlučuje primjenom odredbe čl. 5. st. 3. OZ-a, odnosno kao da je zatraženo da ovrhu odredi drugim sredstvom i na drugom predmetu ovrhe." Županijski sud u Varaždinu: Gž Zk 262/2017-2. 
određivanje zabilježbe ovrhe.

\subsection{Učinak zabilježbe ovrhe}

Učinak zabilježbe ovrhe je da ovrhovoditelj time stječe pravo da svoju tražbinu namiri iz nekretnine (vrijednosti nekretnine koja se prodaje u ovršnom postupku pravo na namirenje) i ako bi treća osoba kasnije stekla vlasništvo te nekretnine (čl. 84. st. 2. OZ). ${ }^{12}$ Nakon zabilježbe ovrhe nije dopušten upis promjene prava vlasništva niti kojega drugog stvarnog prava utemeljenog na raspoložbi ovršenika, bez obzira na to kad je ta raspoložba poduzeta (čl. 84. st. 3. OZ). Primjerice, ovršenik ne može nakon upisa zabilježbe ovrhe prodati nekretninu ili je darovati jer nisu dopuštena dobrovoljna raspolaganja ovršenika tom nekretninom. No, ako neki založni vjerovnik, koji je stekao i upisao hipoteku prije zabilježbe ovrhe, namiruje svoju tražbinu iz vrijednosti nekretnine, ta se nekretnina u tom slučaju može prodati jer se u tom slučaju ne radi o raspolaganju ovršenika. Ta je razlika ključna kod zabilježbe ovrhe i po tome se razlikuje od drugih zabilježbi jer ograničava vlasnika-ovršenika nekretnine da raspolaže tom nekretninom dok u zemljišnim knjigama postoji zabilježba ovrhe. Cilj je te zakonske odredbe spriječiti da se naknadnim promjenama vlasnika nekretnine na temelju raspoložbi ovršenika otežava i odugovlači provedba ovrhe. ${ }^{13}$ Osim toga,

12 Okolnost da je nakon zabilježbe u zemljišnim knjigama prava na namirenje treća osoba stekla vlasništvo nekretnine, nije zapreka da se vjerovnik namiri iz te nekretnine. $U$ tom smislu presuđeno: „Po odredbi čl. 144. st. 1. Zakona o izvršnom postupku u zemljišnoj će se knjizi izvršiti zabilježba rješenja o izvršenju na nekretnini. St. 2. toga članka predviđa da tom zabilježbom vjerovnik stječe pravo da svoje potraživanje namiri iz nekretnine (pravo na namirenje) i u slučaju da treća osoba kasnije stekne na istoj nekretnini pravo vlasništva ili pravo raspolaganja. Po odredbi čl. 33. Zakona o osnovnim vlasničkopravnim odnosima na temelju pravnog posla pravo vlasništva na nekretninama stječe se upisom u javne knjige. U konkretnom slučaju tuženikov dužnik je bio upisan u zemljišnim knjigama kao vlasnik 12. kolovoza 1991. godine kada je prema podacima u spisu doneseno rješenje o izvršenju kojim je dopuštena spomenuta zabilježba, dok je presuda kojom je raskinut kupoprodajni ugovor temeljem kojega je tuženikov dužnik ishodio upis prava vlasništva nekretnina na svoje ime, postala pravomoćna dana 7. siječnja 1993. godine. Prema tome, tužitelj je nakon izvršene zabilježbe stekao na istim nekretninama pravo vlasništva. Stoga je prije navedenom zabilježbom tuženik stekao pravo da potraživanje prema svom dužniku D. T. namiri iz njegovoga suvlasničkog dijela nekretnina unatoč tome što je na tom dijelu tužitelj kasnije stekao pravo vlasništva." Vrhovni sud Republike Hrvatske, Rev 2797/93, od 18. 10. 1995.

13 Upisana zabilježba ovrhe u zemljišnoj knjizi zapreka je za upis založnog prava na toj nekretnini. U tom smislu presuđeno: „Dakle, prema sadržaju citiranih odredbi predbilježba se može dopustiti ako isprava na temelju koje se zahtijeva upis ne odgovara svim posebnim pretpostavkama za uknjižbu. U konkretnom slučaju prijedlog za uknjižbu založnog prava predlagatelj temelji na Sporazumu o osiguranju novčane tražbine od 28. travnja 2015. sklopljenom između predlagatelja i protustranke i navedena isprava nema nikakvih nedostataka zbog kojih se traženi upis ne bi mogao provesti. Međutim, u trenutku podnošenja prijedloga za upis založnog prava na nekretninama obuhvaćenim prijedlogom upisana je zabilježba ovrhe, a u smislu odredbe čl. 107 ZZK za odlučivanje o prijedlogu za upis mjerodavno je stanje u času kad je taj prijedlog stigao zemljišnoknjižnom sudu. Odredbom čl. 84. st. 3. OZ-a propisano je da nakon zabilježbe ovrhe nije dopušten upis promjene prava vlasništva niti kojeg drugog stvarnog prava utemeljen na raspoložbi ovršenika, bez obzira na to kad je ta raspoložba 
tom se odredbom nastoji postići da se zabranom upisa drugih stvarnih prava, npr. stvarnim služnostima, koja ne prestaju prodajom nekretnine, ne isprovocira smanjenje interesa za kupnju na javnoj dražbi i smanjenje vrijednosti nekretnine. Međutim, nije zabranjeno upisati pravo vlasništva ili koje drugo stvarno pravo koje nije utemeljeno na raspoložbi ovršenika (primjerice ako je treća osoba stekla pravo vlasništva na temelju sudske odluke, nasljeđivanja ili zakona).

Cilj je ove odredbe zaštititi nekretninu na kojoj se provodi ovrha od daljnjih raspoložbi ovršenika kako bi se omogućila brza i djelotvorna naplata tražbine zbog koje se ovrha provodi. Dužnost je države omogućiti funkcioniranje pravnog sustava kao koherentnog i konzistentnog sustava pravnih pravila koja udovoljavaju načelu vladavine prava, kao najviše vrednote ustavnog poretka Republike Hrvatske.

Učinak zabilježbe je i u tomu da ovrhovoditelj koji je predložio ovrhu, a nije prije stekao založno pravo, stječe zabilježbom ovrhe pravo da se iz nekretnine namiri prije osobe koja na toj nekretnini kasnije stekne založno pravo ili pravo na namirenje (čl. 84. st. 6. OZ). Moguća je situacija da se tijekom ovršnog postupka promijeni vlasnik nekretnine. Ta promjena, međutim, ne sprječava da se, ako je upisana zabilježba ovrhe, postupak nastavi protiv novoga vlasnika kao ovršenika. Pritom sve radnje poduzete prije toga ostaju na snazi i novi vlasnik ne može u postupku poduzimati one radnje koje ne bi mogao poduzeti prijašnji vlasnik da do promjene vlasništva nije došlo (čl. 84. st. 4. OZ). U tom će se slučaju na prijedlog ovrhovoditelja donijeti rješenje o nastavljanju ovršnog postupka protiv novoga vlasnika kao ovršenika u tom postupku. Protiv toga rješenja novi vlasnik nema pravo na žalbu (čl. 84. st. 5. OZ). Nakon upisa zabilježbe ovrhe ne može se za namirenje druge tražbine istoga ili drugoga ovrhovoditelja na toj nekretnini provesti poseban ovršni postupak. Ovrhovoditelj za čiju je tražbinu kasnije određena ovrha na istoj nekretnini stupa u već pokrenuti ovršni postupak (čl. 85. st. 1. i 2. OZ).

Dakle, učinak zabilježbe ovrhe je: 1. da nakon upisa zabilježbe ovrhe nije dopušten upis promjene prava vlasništva niti kojega drugog stvarnog prava utemeljen na raspoložbi ovršenika bez obzira na to kad je ta raspoložba poduzeta; 2. da ako nekretnina promijeni vlasnika, ovrhovoditelj stječe pravo da tražbinu namiri iz vrijednosti nekretnine (pravo na namirenje), pa se postupak može nastaviti protiv novoga vlasnika; 3 . da radnje koje su poduzete ostaju punovažne, a novi vlasnik ne može poduzimati one radnje koje ne bi mogao ni prijašnji vlasnik; 4. da ovrhovoditelj koji je predložio ovrhu, a nije prije stekao hipoteku, stječe zabilježbom pravo da se iz nekretnine namiri prije osobe koja na toj nekretnini kasnije stekne hipoteku ili pravo na namirenje; 5. da nakon upisa zabilježbe ne može na toj nekretnini provesti poseban ovršni postupak za namirenje druge tražbine, već novi ovrhovoditelj stupa u već pokrenuti postupak, najkasnije do pravomoćnosti rješenja o dosudi. ${ }^{14}$

poduzeta. To znači da nije dopušten upis stvarnih prava koje bi treća osoba stekla pravnim poslom s ovršenikom, bez obzira na vrijeme sklapanja. Obzirom na sadržaj odredbe čl. 84. st. 3. OZ-a upisana zabilježba ovrhe na nekretninama protustranke predstavlja zapreku za upis založnog prava na istim nekretninama.“ Županijski sud u Varaždinu: Gž Zk 210/2018-2.

14 Tako Kontrec, D., Ovrha na nekretnini, Hrvatska gospodarska komora - sektor za trgovinu dvadeset i treći forum poslovanja nekretninama, str. 6 . 


\subsection{Upis zabiljez̆be ovrhe}

Pri upisu zabilježbe zemljišnoknjižni sud postupa prema odredbi čl. 108. st. 2. ZZK-a, što znači da ispituje jedino je li ovlašteni sud odredio zabilježbu ovrhe i jesu li ispunjeni uvjeti da se ta zabilježba može upisati u zemljišnoj knjizi s obzirom na stanje zemljišne knjige (je li ovršenik ujedno i upisani ili barem predbilježeni zemljišnoknjižni vlasnik). ${ }^{15} \mathrm{Ne}$ ispune li se pretpostavke iz čl. 108. st. 2. ZZK-a, zemljišnoknjižni sud odbit će upis zabilježbe ovrhe. Varijante neudovoljavanja pretpostavkama iz čl. 108. st. 2. ZZK-a mogu se odnositi na to: 1. da je upis odredilo nenadležno tijelo kada se primjenom čl. 109. st. 5. ZZK-a odbija dopuštenje upisa i zabilježi odbijanje odnosno b) da upis nije provediv s obzirom na stanje zemljišne knjige. Tada će se na temelju čl. 111. st. 1. ZZK-a prijedlog odbiti i zabilježiti odbijanje prijedloga. ${ }^{16}$

$\mathrm{Na}$ temelju prijedloga za ovrhu općenito na imovini ovršenika podnesenog javnom bilježniku, da na temelju rješenja o ovrsi donesenog po tom prijedlogu nije podnesen i prijedlog nadležnom sudu za određivanje sudske ovrhe na nekretnini, nije moguće s uspjehom tražiti zabilježbu pokretanja ovrhe, jer se ne radi o postupku u kojem bi mogao biti određen upis u zemljišnu knjigu. ${ }^{17}$

15 Kada su ostvarene pretpostavke za zabilježbu ovrhe iz odredbe čl. 84. st. 1. Ovršnog zakona, zemljišnoknjižni sud ne može ispitivati pretpostavke za donošenje tog rješenja, već će se u smislu odredbe čl. 108. st. 2. Zakona o zemljišnim knjigama ograničiti na pitanje je li upis provediv s obzirom na stanje zemljišne knjige, a glede ostalih pretpostavki odlučuje onaj sud ili drugo tijelo koje upis dopušta. „Odredbom čl. 84. st. 1. Ovršnog zakona (dalje OZ) propisano je da čim donese rješenje o ovrsi, sud će po službenoj dužnosti zatražiti da se u zemljišnoj knjizi upiše zabilježba ovrhe. Odredbom čl. 108. st. 2. Zakona o zemljišnim knjigama (dalje ZZK) propisano je da kad zemljišnoknjižni upis određuje drugi sud ili drugo nadležno tijelo, a ne zemljišnoknjižni sud, zemljišnoknjižni sud će se ograničiti na ispitivanje je li upis odredilo za to nadležno tijelo te je li upis provediv s obzirom na stanje zemljišne knjige, a glede ostalih pretpostavki odlučuje onaj sud ili drugo tijelo koje upis dopušta. Sadržajno u biti protivnik upisa smatra da uopće nije bilo dopušteno donijeti rješenje o ovrsi, te zatim, naravno, i naložiti zabilježbu ovrhe, no u smislu odredbe čl. 108. st. 2. ZZK-a zemljišnoknjižni sud ne može ispitivati pretpostavke za donošenje rješenja o ovrsi. Katastarska Općina S. spada pod nadležnost Općinskog suda u Rijeci, te je stoga valjano prvostupanjski sud odredio zabilježbu ovrhe u smislu odredbe čl. 108. st. 2. ZZK-a, jer su ostvarene pretpostavke iz odredbe čl. 84 . Ovršnog zakona. Eventualna žalba na rješenje o ovrsi, odnosno nepravomoćnost rješenja o ovrsi nije zapreka za donošenje rješenja o zabilježbi, jer se rješenje o ovrsi zabilježuje prije nastupa pravomoćnosti, a ovo sve je praktično zabilježba ovrhe i prva ovršna radnja u postupku ovrhe na nekretnini radi naplate novčane tražbine. Slijedom navedenog, kako je prvostupanjski sud na pravilno i potpuno utvrđeno činjenično stanje pravilno primijenio materijalno pravo, a nije počinio povrede postupka, valjalo je na temelju odredbe čl. 128. st. 3. ZZK-a odbiti žalbu protivnika upisa kao neosnovanu i potvrditi rješenje prvostupanjskog suda.” Županijski sud u Splitu, Gž Zk-141/16, od 7. 6. 2016.

16 Tako Mihelčić, G., u suradnji s Kontrecom, D., Komentar Ovršnog zakona s opsežnom sudskom praksom i abecednim kazalom pojmova, Zagreb, Organizator, 2015., str. 377.

17 U tom smislu presuđeno: „Neosnovano žalitelj prigovara utvrđenom činjeničnom stanju u pogledu osnovanosti prijedloga radi zabilježbe pokretanja postupka jer je prvostupanjski sud utvrdio da je predlagatelj kod javnog bilježnika ishodio rješenje o ovrsi na temelju vjerodostojne isprave radi namirenja novčane tražbine ovrhom općenito na imovini ovršenika. Pravilno je utvrđenje prvostupanjskog suda da se zabilježba pokretanja postupka zatražena primjenom čl. 84.a Zakona o zemljišnim knjigama (dalje ZZK) na točno određenim nekretninama ne može 
Bitno je naglasiti da nakon zabilježbe ovrhe nije dopušten upis promjene prava vlasništva niti kojega drugog stvarnog prava utemeljenog na dobrovoljnoj raspoložbi ovršenika, ${ }^{18}$ neovisno o tomu kada je ta raspoložba poduzeta (prije upisa zabilježbe ovrhe ili nakon toga). ${ }^{19}$

zahtijevati a da predlagatelj nije dostavio dokaz da je pokrenut postupak ovrhe ne nekretninama protustranke podnošenjem sudu prijedloga za promjenu predmeta ovrhe na nekretninama. Prema shvaćanju ovoga Suda, pretpostavka za dopuštanje zabilježbe pokretanja postupka pred sudom ili upravnim tijelom u kojem bi se mogao odrediti upis za koji se ne može upisati zabilježba spora jest da je predlagatelj predao sudu ili upravnom tijelu podnesak na rješavanje na temelju kojega bi se mogao odrediti upis u zemljišnu knjigu, dok sud ili upravno tijelo ne odredi zabilježbu. Takva zabilježba djelovala bi protiv svih onih koji bi kasnije stekli knjižna prava, a po donošenju odluke o prijedlogu, donošenjem rješenja o zabilježbi spora, ista bi bila provedena na onome mjestu koje je osigurala zabilježba pokretanja postupka. Nije sporno da predlagatelj na temelju pravomoćnog rješenja o ovrsi određenog općenito na imovini ovršenika može predložiti promjenu predmeta ovrhe pa i na nekretninama ovršenika, koje mora točno označiti u prijedlogu za promjenu predmeta ovrhe, a u skladu s odredbom čl. 285. u vezi s čl. 79. do čl.82. Ovršnog zakona („Narodne novine”, br. 112/12 - dalje OZ). Pokretanje postupka promjenom predmeta ovrhe na nekretninama ovršenika je pretpostavka za predloženu zabilježbu jer se samo na temelju takvog prijedloga ne može odrediti zabilježba ovrhe iz čl. 84 . OZ-a ili zabilježba odbijanja ovrhe iz čl. 88. ZZK-a dok sud ne odluči o prijedlogu za promjenu predmeta ovrhe donošenjem rješenja o ovrsi ili odbijanjem odnosno odbacivanjem prijedloga za promjenu predmeta ovrhe.” Županijski sud u Bjelovaru, Gž - 2837/14-3, od 16. 4. 2015.

18 Tako Pezo, I., Upisi u zemljišnu knjigu, vrste upisa, pravni temelj, učinci... prateći propisi, Zagreb, Novi informator, 2011., str. 59.

19 Nakon zabilježbe ovrhe ovrhovoditelj stječe pravo na namirenje i onda kada treća osoba kasnije stekne vlasništvo na temelju sudske odluke zbog čega je dopušten upis promjene prava koji nije utemeljen na raspoložbi ovršenika nakon zabilježbe ovrhe. U tom smislu presuđeno: „Sud je usvojio prigovor treće osobe K. V. i proglasio nedopuštenom ovrhu na suvlasničkom dijelu od 1/4 nekretnine koja je pobliže označena u izreci rješenja i koja je predmet ovrhe u ovom ovršnom postupku. Polazeći od razloga koji su dati u pobijanom rješenju K. V. stekla je suvlasnički dio na nekretnini na temelju presude, pobliže označene u obrazloženju rješenja, tako da je svoj prigovor potkrijepila javnom ispravom, odnosno izvatkom iz zemljišne knjige. Donoseći ovakvu odluku sud se pozvao na čl. 56. st. 1. Ovršnog zakona (NN $57 / 96$ i 29/99, dalje OZ). Prema podacima koje sadrži spis predmeta ova promjena u zemljišnoj knjizi uslijedila je nakon što je u zemljišnoj knjizi zabilježena ovrha na predmetnoj nekretnini, pa iz obrazloženja pobijanog rješenja proizlazi pravni stav suda iako nije posebno obrazložen da činjenično stanje ukazuje na odredbe čl. 79. st. 3. OZ-a, a koje predviđaju da nakon zabilježbe ovrhe nije dopušten upis promjene prava vlasništva na predmetu ovrhe koji je utemeljen na raspoložbi ovršenika. Drugim riječima, do promjene u zemljišnoj knjizi je došlo na temelju sudske odluke, a ne na dobrovoljnoj raspoložbi ovršenika, pa bi to značilo da treća osoba K. V. raspolaže sa takvim pravom koje sprječava ovrhu na njenom suvlasničkom dijelu. Međutim, sud je propustio uočiti i odredbe čl. 79. st. 1. i 2. OZ-a, a koje predviđaju da ovrhovoditelj zabilježbom ovrhe stječe pravo da svoju tražbinu namiri iz nekretnine i u slučaju da treća osoba kasnije stekne vlasništvo te nekretnine. Ove odredbe potrebno je povezati s odredbama st. 4. ovog zakonskog članka, a smisao je tih odredbi da promjena vlasnika nekretnine ne sprječava da se ovršni postupak nastavi protiv novog vlasnika kao ovršenika i da ovrhovoditelj ostvari svoje pravo na namirenje iz vrijednosti nekretnine koja je predmet ovrhe. Ako se na ovaj način sagleda spor, odnosno ocijeni prigovor treće osobe K. V., tada se zaključuje da ona nema takvo pravo koje sprječava ovrhu, već naprotiv, ona je stekla pravo suvlasništva, kako to proizlazi iz spisa predmeta, ali se u tom dijelu našla u procesnoj poziciji ovršenika." Županijski sud u Koprivnici, Gž - 1363/01-2, od 11. 12. 2001. 
Ova odredba i njezin učinak razlikuje zabilježbu određenu na temelju ZZK-a i isključuje publicitetnu narav zabilježbe te sprječava daljnje upise i pravni promet nekretnina, ali samo u odnosu na osnove za promjenu zemljišnoknjižnog stanja utemeljene na raspoložbi ovršenika. ${ }^{20}$ Svrha je te odredbe da se spriječi otežavanje provedbe ovrhe time što bi dispozicijom ovršenika došlo do promjene prava vlasništva na nekretnini ovršenika, kao i drugoga stvarnog prava. ${ }^{21}$

Prvi problemi pri daljnjoj uknjižbi mogu nastati kada se postavi pitanje koji su to pravni naslovi za stjecanje vlasništva utemeljeni na raspoložbi ovršenika. Svojom dispozicijom ovršenik može zaključiti ugovor o prodaji nekretnine, ugovor o darovanju, zamjeni ili opteretiti nekretninu zasnivanjem služnosti, te na drugi način utemeljen na njegovoj raspoložbi onemogućiti ili dopustiti promjenu prava vlasništva niti bilo kojega drugog stvarnog prava u zemljišnim knjigama. ${ }^{22}$ Time se postiže svrha i cilj ove odredbe, a to je da se spriječi postupanje ovršenika usmjereno na odugovlačenje ovršnog postupka. ${ }^{23}$

Do promjene prava vlasništva nakon upisane zabilježbe ovrhe može doći na temelju presude kojom se mijenjaju knjižna prava s ovršenika na drugu osobu. ${ }^{24}$

Isto tako promjena vlasnika nekretnine tijekom ovršnog postupka ne sprječava da se taj postupak nastavi protiv novoga vlasnika kao ovršenika, pri čemu o tomu treba voditi računa u ovršnom postupku. Sve radnje poduzete prije toga ostaju na snazi i novi vlasnik ne može u postupku poduzimati one radnje koje ne bi mogao poduzeti raniji vlasnik da do promjene vlasništva nije došlo. U ovršnom postupku će, ako dođe do promjene vlasnika, sud na prijedlog ovrhovoditelja donijeti rješenje o nastavljanju ovršnog postupka protiv novoga vlasnika kao ovršenika, pri čemu taj novi vlasnik nema pravo žalbe na takvo rješenje. ${ }^{25}$

Ovrhovoditelj koji je predložio ovrhu, stječe ujedno i založno pravo, ako ga nije stekao ranije, te zabilježbom ovrhe stječe pravo da se iz nekretnine namiri prije osobe

20 Čizmić, J., Šago, D., Kačer, H., op. cit., str. 428.

21 Zabilježba ovrhe nije potrebna ako je vjerovnik već prije zabilježio da je podnio tužbu protiv vlasnika nekretnine. Isto vrijedi i ako je već zabilježio otkaz o kojem je ovisilo dospijeće njegove tražbine. Zabilježeni otkaz ili tužba djelovat će i protiv svakoga kasnijeg vlasnika nekretnine, pa će se na temelju ovršne presude čije je donošenje ishođeno zabilježenom tužbom ili zabilježenim otkazom, moći provesti namirenjem iz nekretnine bez obzira na to tko je u međuvremenu postao njezinim vlasnikom.

22 Rješenjem ŽS u Varaždinu prihvaćena je žalba i preinačeno rješenje na način da je odbijen prijedlog predlagatelja da se nekretnine upišu u zemljišnim knjigama na temelju darovnog ugovora od 29. lipnja 2004. jer je 21. svibnja 2004. izvršena zabilježba ovrhe na nekretninama protustranke (ŽS u Varaždinu Gž - 1708/04).

23 Tako Milaković, G., Provedba upisa u zemljišne knjige nakon upisane zabilježbe ovrhe, Hrvatska pravna revija, 3/2007., str. 71.

24 Problem nije provedba upisa utemeljenog na presudi koja je rezultat kontradiktornog postupka, već se problem pojavljuje onda kada je osnova za promjenu prava vlasništva presuda na temelju priznanja, presuda zbog izostanka, presuda zbog ogluhe te sudska nagodba. Postavlja se pitanje sadrže li ove presude i sudska nagodba element dispozitivnosti koji bi doveo do zaključka da se radi o raspoložbi ovršenika usmjerenoj na promjenu prava vlasništva nakon upisane zabilježbe ovrhe. Opširnije Milaković, G., op. cit. str. 71.

25 Tako Kontrec, D., Bulka, Z., Aktualna pitanja zemljišnoknjižnog prava - edukacija za zemljišnoknjižne referente, Zagreb, Pravosudna akademija, 2016., str. 30. 
koja je na toj nekretnini kasnije stekla založno pravo ili pravo na namirenje. Često se u praksi događa da treće osobe budu upućene u ovrsi na parnicu radi utvrđenja da ovrha na nekretnini nije dopuštena. Odluke su u tim slučajevima raznolike i ovise o činjeničnim utvrđenjima, pri čemu uspjeh u parnici ovisi prije svega o poštenju (savjesnosti) te treće osobe.

\subsection{Pristupanje ovrsi}

Nakon upisa zabilježbe ovrhe ne može se za namirenje druge tražbine istoga ili drugoga ovrhovoditelja na toj nekretnini provesti poseban ovršni postupak (čl. 85. st. 1. OZ). Ovrhovoditelj za čiju je tražbinu kasnije određena ovrha na istoj nekretnini stupa u već pokrenuti ovršni postupak (čl. 85. st. 2. OZ). Pokrenutom ovršnom postupku može se pristupiti do pravomoćnosti rješenja o dosudi nekretnine kupcu (čl. 85. st. 3. OZ). O pristupanju postupku sud će obavijestiti ovrhovoditelja u čiju je korist prije obavljena zabilježba (čl. 85. st. 4. OZ). Razlozi zbog kojih ovrha nije dopuštena u korist pojedinih od više ovrhovoditelja u čiju se korist ovrha provodi na istoj nekretnini, odnosno razlozi za obustavu ovrhe u odnosu na pojedine od ovrhovoditelja ne utječu na provedbu postupka u korist drugih ovrhovoditelja (čl. 85. st. 5. OZ). Ako se razlog za odgodu ovrhe tiče samo jednoga od više ovrhovoditelja, ovrha se neće odgoditi, nego će sud pri donošenju rješenja o namirenju odrediti odgodu namirenja toga ovrhovoditelja sve dok se postupak u odnosu na njega ne nastavi. Sredstva namijenjena namirenju toga ovrhovoditelja sud će pohraniti do nastavka postupka. Ako postupak ne bude nastavljen, ta će se sredstva upotrijebiti za namirenje drugih ovrhovoditelja, odnosno predat će se ovršeniku (čl. 85. st. 6. OZ).

\subsection{Brisanje zabilježbe ovrhe}

Za neke od zabilježbi predviđa se brisanje po službenoj dužnosti s protekom određenog vremena, no većina se briše po prijedlogu stranke, kojem treba priložiti svojevrsno rješenje iz kojeg je vidljivo da se situacija promijenila, odnosno da je dugovanje prema ovrhovoditelju podmireno ili treba biti izbrisana po nekom drugom pravnom temelju.

Zabilježba ovrhe brisat će se nakon nekog od načina pravomoćnog dovršetka ili obustave postupka ovrhe. ${ }^{26}$

26 Upis brisanja zabilježbe ovrhe treba prihvatiti kada je uz prijedlog za takav upis priložena pravomoćna odluka ovršnog suda iz koje proizlazi da je postupak obustavljen. U tom smislu presuđeno: „Ovrha na nekretninama provodi se zabilježbom ovrhe u zemljišnoj knjizi, utvrđivanjem vrijednosti nekretnine, prodajom nekretnine i namirenjem ovrhovoditelja iz iznosa dobivenog prodajom. Čim je donio rješenje o ovrsi, sud je po službenoj dužnosti zatražio upis zabilježbe ovrhe u zemljišnoj knjizi. Tom zabilježbom ovrhovoditelj je stekao pravo da svoju tražbinu namiri iz nekretnina, ustanovljeno kao pravo na namirenje i u slučaju da treća osoba kasnije stekne vlasništvo te nekretnine. Posljedica toga je da nakon zabilježbe ovrhe nije dopušten upis promjene prava vlasništva utemeljen na raspoložbi ovršenika, bez obzira na to kada je ta raspoložba poduzeta. Međutim, ako do toga i dođe, takva promjena vlasnika nekretnine tijekom ovršnog postupka ne sprječava da se postupak nastavi protiv novog vlasnika kao ovršenika. Sve radnje poduzete prije toga ostaju na snazi i novi vlasnik ne može u postupku 


\section{ZABILJEŽBA OVRŠIVOSTI TRAŽBINE OSIGURANE HIPOTEKOM}

Rješenjem o osiguranju sud će odrediti uknjižbu hipoteke i zabilježbu ovršivosti i naložiti da se hipoteka i zabilježba ovršivosti upišu s onim prvenstvenim redom od dana ovrhovoditeljeva stjecanja prava na namirenje, dakle $s$ danom zabilježbe ovrhe. Zabilježba ovršivosti tražbine osigurane hipotekom upisuje se u teretovnicu po službenoj dužnosti u postupku osiguranja pri prisilnom osnivanju založnog prava na nekretnini, istodobno s uknjižbom hipoteke kao mjerom osiguranja zasnovanom u postupku osiguranja za novčanu tražbinu za koju postoji ovršna isprava, ili na prijedlog vjerovnika čija je tražbina postala ovršna ako je za tu tražbinu već ranije na osnovi ugovora stekao hipoteku ili ako je već ranije kao prethodna mjera osiguranja predbilježena hipoteka. ${ }^{27}$

Retroaktivnost upisa hipoteke i zabilježbe ovršivosti u službi su svojevrsnog nepravog očuvanja načela knjižnog prednika. Naime, ako je tijekom ovršnog postupka (a nakon zabilježbe ovrhe) došlo do promjene vlasnika nekretnine (čl. 79. st. 4. OZ) i ovrha se nastavila protiv novog vlasnika, u trenutku podnošenja prijedloga za osiguranje predlagatelj osiguranja/ovrhovoditelj (koji je pokrenuo ovrhu na temelju ovršne isprave protiv ranijeg vlasnika i zabilježbom ovrhe stekao pravo namirenja protiv novog vlasnika) nema takav naslov i u odnosu na novoga zemljišnoknjižnog vlasnika. Tako će hipoteka biti osnovana na temelju ovlaštenja iz čl. 97. OZ-a, de facto, retroaktivno u skladu sa zemljišnoknjižnim stanjem kakvo je bilo u trenutku zabilježbe ovrhe. ${ }^{28}$

poduzimati one radnje koje ne bi mogao poduzimati prijašnji vlasnik da do promjene vlasništva nije došlo. Na sve to nas upućuje normativni sadržaj odredaba čl. 75. i 79. Ovršnog zakona („Narodne novine”, br. 57/96, 29/99, 42/00, 173/03, 194/03, 151/04, 88/05, 121/05 i 67/08 - dalje OZ). Zabilježba se može odrediti kada je to predviđeno, ne samo odredbama Zakona o zemljišnim knjigama (dalje ZZK), već i drugim zakonom uključujući i OZ, o čemu je u ovoj pravnoj stvari riječ. Na taj način osnovno i glavno sredstvo zaštite ovrhovoditelja je upis zabilježbe ovršnog postupka u zemljišne knjige po službenoj dužnosti odmah po donošenju rješenja. Vodeći računa o tim odredbama, koje supstancijalno štite interese ovrhovoditelja, moguće je i dopušteno provesti upis brisanja zabilježbe na način kako to uređuje odredba čl. 83 . i 84. ZZK-a, s tom razlikom da uz prijedlog za takav upis, pa i u onoj situaciji kada ga dostavlja ovršni sud, treba biti priložena pravomoćna odluka iz koje proizlazi da je postupak obustavljen, na način kako to propisuje čl. 83. st. 1. ZZK-a. Tek se u tom slučaju zabilježba može izbrisati, bilo po nalogu suda, bilo po prijedlogu nositelja knjižnog prava na koje se zabilježba odnosi. Time su za upis brisanja zabilježbe ovrhe ustanovljena drugačija pravila od onih koja vrijede, prema čl. 79. st. 1. OZ-a, za upis zabilježbe ovrhe odmah nakon donošenja rješenja o ovrsi na nekretninama.” Županijski sud u Rijeci, Gž - 3030/10, od 15. 11. 2012.

27 Tako Pezo, I., op. cit., str. 86-87.

28 U praksi se problematizira bi li ovršni sud trebao sačekati pravomoćnost rješenja o obustavi ovrhe, odnosno brisanju zabilježbe ovrhe, pa tek onda odlučiti o osiguranju, ili to može učiniti istodobno te treba li rješenje o osiguranju dostaviti po pravomoćnosti ili ranije zemljišnoknjižnom sudu. Ima mišljenja da je u svrhu očuvanja prvenstvenog reda korisno istim rješenje odlučiti i o obustavi ovrhe (i brisanju zabilježbe ovrhe po pravomoćnosti obustave) i odrediti osiguranje uknjižbom hipoteke i zabilježbom ovršivosti s prvenstvenim redom zabilježbe ovrhe, i takvo rješenje dostaviti zemljišnoknjižnom sudu radi plombiranja, ali o ovom pitanju u praksi nema 
Učinak je ove zabilježbe, zajedno s uknjižbom prisilnoga založnog prava, da će se ovrha na nekretninama moći provesti i prema trećoj osobi koja je tu nekretninu stekla i nakon njezina upisa. Ako se ova zabilježba upisuje za tražbinu za koju je ranije samo predbilježena hipoteka kao prethodna mjera osiguranja, jer u trenutku određivanja te prethodne mjere, tražbina još nije bila ovršna, tada će upis ove zabilježbe imati i pravne učinke opravdanja te predbilježbe. ${ }^{29}$

U rješenju kojim će odrediti osiguranje, ovršni sud odredit će da se u zemljišne knjige naznači ovršivost tražbine ${ }^{30}$ radi osiguranja koje je uknjižba određena. Pravni učinak uknjižbe i zabilježbe ovršivosti očituje se u tomu da se ovrha na toj nekretnini može provesti i prema trećem koji nekretninu kasnije stekne. U tom slučaju ovrha će se odrediti protiv novog vlasnika na temelju ovršne isprave kojom je u zemljišne knjige upisana prisilna hipoteka i zabilježba ovršivosti te izvatka iz zemljišne knjige iz kojeg je vidljivo da je ta osoba upisana nakon upisa hipoteke i zabilježbe ovršivosti. ${ }^{31}$ Smatramo da bi ovršni sud trebao po službenoj dužnosti rješenje o osiguranju dostaviti zemljišnoknjižnom sudu i da će tek nakon što zemljišnoknjižni sud odluči, odnosno dopusti upis hipoteke, ona i biti osnovana. Žalbu je moguće uložiti i protiv rješenja o osiguranju kao i protiv rješenja kojim je zemljišnoknjižni sud odlučio o upisu.

\section{ZABILJEŽBA PRIVREMENE MJERE OSIGURANJA ZABRANOM OTUĐENJA ILI OPTEREĆENJA NEKRETNINE}

Privremene mjere možemo definirati kao sredstva kojima je cilj stvaranje uvjeta za buduće ostvarenje tražbina vjerovnika na temelju odluke koja će biti ili koja je već donesena o glavnom pitanju (u glavnom postupku). ${ }^{32}$ Zadaća je privremenih mjera ostvarenje regulacijske funkcije brzog i privremenog uređenja odnosa između stranaka u sporu čija je bit u ovlaštenju suda da određene pravne odnose privremeno uredi prema svojoj slobodnoj ocjeni. ${ }^{33}$

Privremene mjere koje se sastoje u zabranama i nalozima smatraju se provedenima dostavom osobi koje se tiču, odnosno zemljišnoknjižnom odjelu suda

konsenzusa. Tako Mihelčić, G., Prisilno sudsko hipotekarno osiguranje tražbine, Zbornik Pravnog fakulteta Sveučilišta u Rijeci, vol. 28, 1/2007, str. 24.

29 Više Bugarin, B., Ovrha na nekretninama i zemljišne knjige: ovršni zemljišnoknjižni upisi, Hrvatska pravna revija, 1/2015., str. 68-69.

30 Naznačiti ovršivost znači da će sud zabilježiti ovršivost tražbine osigurane hipotekom. Prema Josipović, T., Komentar Zakona o zemljišnim knjigama, Zagreb, Informator, 1998., str. 170.

31 U dijelu prakse zastupa se stajalište da bi ovršni sud kada donese rješenje o osiguranju, trebao po službenoj dužnosti isto dostaviti zemljišnoknjižnom sudu, i to prije pravomoćnosti rješenja, a u slučaju kada odbije ili odbaci prijedlog za osiguranje, po službenoj dužnosti odrediti zabilježbu odbijenog odnosno odbačenog prijedloga za osiguranje. U teoriji ima drukčijih mišljenja prema kojima se rješenje o osiguranju dostavlja po službenoj dužnosti, ali tek nakon pravomoćnosti. Tako Dika, M., Sudsko i javnobilježničko založnopravno osiguranje tražbina na temelju sporazuma stranaka, u: Barbić, J. i dr., Novo ovršno i stečajno pravo, Zagreb, 1996., str. 81.

32 Tako Dika, M., Građansko ovršno pravo, Opće građansko ovršno pravo, Zagreb, Narodne novine, 2007., str. 847.

33 Ibid. str. 847-848. 
ili drugom upisniku. Učinak zabilježbe zabrane otuđenja ili opterećenja nekretnine ili stvarnih prava upisanih na nekretnini je u tomu što se upisima obavljenim u zemljišnoj knjizi na temelju dobrovoljne raspoložbe protivnika osiguranja, nakon upisa zabilježbe zabrane, mogu steći u odnosu prema predlagatelju osiguranja prava na nekretnini ili pravu na njoj upisanom samo ako predlagatelj osiguranja bude pravomoćno odbijen sa svojim zahtjevom u postupku koji je pokrenuo radi ostvarenja tražbine za čije je osiguranje zabilježba upisana. ${ }^{34} \mathrm{Na}$ temelju ovršne isprave stečene u postupku koji je pokrenuo protiv protivnika osiguranja radi ostvarenja tražbine za čije je osiguranje zabilježba zabrane upisana te dokaza da je osoba koja je stekla određeno pravo na nekretnini ili pravu upisanom na nekretnini na temelju dobrovoljne raspoložbe protivnika osiguranja to pravo stekla nakon upisa zabrane, predlagatelj osiguranja može izravno protiv te osobe tražiti ovrhu radi ostvarenja svoga prava utvrđenoga ovršnom ispravom.

Zabilježba zabrane otuđenja ili opterećenja nekretnine kao privremene mjere osiguranja donesene rješenjem suda upisuje se u teretovnicu na temelju sudske odluke, a po dostavi te odluke zemljišnoknjižnom sudu od drugog suda ili po prijedlogu stranke. Upis ove zabilježbe određene rješenjem civilnog suda ne sprječava da dužnik i dalje raspolaže nekretninom, a njezin je učinak da vjerovnik može kada se ispune pretpostavke tražiti ovrhu na toj nekretnini i protiv svakoga kasnijeg stjecatelja nakon njezina upisa. Ako je upisana zabilježba određena kao privremena mjera osiguranja nenovčane tražbine, sva raspolaganja dužnika čine se uvjetnim ovisno o uspjehu predlagatelja osiguranja u sporu koji se vodi glede te nekretnine ili prava na njoj. Odnosno, kada je predlagatelj osiguranja uspio u sporu, on može tražiti ovrhu

34 Pravni učinak zabrane otuđenja nekretnina jest u tomu što predlagatelj osiguranja može predložiti ovrhu radi naplate svoje tražbine kad ona postane ovršna na nekretnini na koju se zabrana odnosi bez obzira na to što je poslije te zabrane treća osoba stekla i uknjižila pravo vlasništva na toj nekretnini, iz kojeg razloga nema zapreke da zemljišnoknjižni sud provede uknjižbu prava vlasništva na treću osobu unatoč uknjiženoj zabrani. "Što se tiče zabilježbe o ovrsi, odnosno otuđenja i opterećenja, sud prvoga stupnja očigledno nije imao u vidu odredbu čl. 297. st. 5. Ovršnog zakona (dalje: OZ). Naime, učinak zabrane otuđenja i opterećenja se sastoji u tome što ovrhovoditelj, odnosno založni vjerovnik može predložiti ovrhu radi naplate svoje tražbine kad ona postane ovršna na nekretnini uknjiženoj u zemljišnoj knjizi bez obzira na to što je poslije te zabrane treća osoba, na temelju dobrovoljne raspoložbe, stekla pravo vlasništva na tim nekretninama. Dakle, imajući u vidu naprijed spomenute zakonske odredbe, očigledno je da nema zapreke, prema stajalištu ovog Suda, da se pobijani dio rješenja provede $u$ zemljišnim knjigama. Prvostupanjski sud je osobito ispustio iz vida da se u konkretnom slučaju ne radi o raspoložbi vlasnika nekretnine upisane u z.k.ul. k.o. Lj., odnosno sada pok. L. S. Ne radi se o raspoložbi, već o pravu nasljeđivanja. Naime, časom smrti ostavitelja sva prava i sve njegove obveze prelaze na nasljednike.

To valja osobito naglasiti. S druge strane, s obzirom da je već u tijeku ovršni postupak, taj postupak se mora i nastaviti. Ovršni postupak protiv ostavitelja kao ovršenika započeo je 1998. Ostavitelj je umro 26. travnja 2005. Ne može se voditi postupak protiv osobe čija su prava i obveze prestale smrću. Taj postupak se može voditi samo ako se nasljednici prihvate nasljeđa, što je u konkretnom predmetu i slučaj. Naime, kada se rješenje o nasljeđivanju ne bi provelo u zemljišnim knjigama glede predmetnih nekretnina, upitno je na koji način bi založni vjerovnici ostvarili svoja prava, odnosno upitno je u kojem postupku i koje osobe bi u tom postupku bile na pasivnoj strani.” Županijski sud u Varaždinu, Gž-1391/05-2, od 8. 8. 2005. 
protiv svake treće osobe koja je stekla nekretninu ili pravo, a kada je predlagatelj pravomoćno odbijen s tužbenim zahtjevom, treće osobe postat će bezuvjetni nositelji upisanog prava. ${ }^{35}$

Ova se zabilježba provodi protiv volje vlasnika, kako bi se spriječilo da vlasnik raspolaže nekretninom odnosno da je optereti, a sve radi osiguranja neke novčane ili nenovčane tražbine vjerovnika na čiji je prijedlog rješenje o određivanju privremene mjere i doneseno. Kod zabilježbe zabrane otuđenja ili opterećenja na temelju pravnog posla ne radi se o osiguranju tražbine kako bi se nekretnina „sačuvala“ za kasniju ovrhu, niti se ona provodi protiv vlasnikove volje. ${ }^{36}$ Upravo je ova zabilježba odraz volje vlasnika i provodi se u povodu njegovog prijedloga. Motivi zbog kojih vlasnik odlučuje svoju nekretninu na neki način izuzeti iz daljnjega pravnog prometa, odnosno ograničiti svoje pravo vlasništva irelevantni su. Učinci zabilježbe privremene mjere osiguranja zabranom otuđenja ili opterećenja propisane su izričitim odredbama OZ-a i nemaju kao posljedicu onemogućavanje daljnjeg prometa, već olakšavanje ovrhe protiv eventualnog stjecatelja, dok zabrana otuđenja ili opterećenja na temelju pravnog posla ima upravo učinak sprječavanja, odnosno otežavanja daljnjega pravnog prometa.

\section{UMJESTO ZAKLJUČKA}

Zemljišnoknjižni sudovi svakodnevno se susreću s različitim vrstama zabilježbi koje imaju svoje specifičnosti i različito utječu na sadržaj knjižnog prava i na mogućnost daljnjeg upisa u zemljišnim knjigama nakon upisane zabilježbe. Zabilježba ne znači i ne može značiti stjecanje bilo kakvih prava, ona je tek u funkciji stvaranja pretpostavki da se neka prava mogu steći pod određenim uvjetima. Zabilježbe koje su vezane za ovršni postupak ne moraju biti vezane isključivo za Ovršni zakon. Primjerice, zabilježba pokretanja postupka i zabilježba odbijanja ovrhe, dvije su zabilježbe koje su propisane odredbama ZZK-a. Zabilježba pokretanja postupka popunjava određenu prazninu koja se javlja u vremenu od podnošenja prijedloga za pokretanje ovršnog postupka i zabilježbe ovrhe. Zabilježba odbijanja ovrhe (čl. 88. ZZK-a) provodi se kad ovršni sud odbije prijedlog za ovrhu na nekretnini radi naplate tražbine za koju nije bila upisana hipoteka. ${ }^{37}$ Naredba bi trebala biti inkorporirana u izreku rješenja ovršnog suda kojim se odbija prijedlog za ovrhu na određenoj nekretnini, a to bi se rješenje zemljišnoknjižnom sudu trebalo otpremiti nepravomoćno, istodobno $\mathrm{s}$ otpremom ovrhovoditelju. ${ }^{38}$ Osnovni je cilj zabilježbe odbijanja ovrhe osiguranje prvenstvenog reda za namirenje tražbine ako se u povodu žalbe ovrhovoditelja (vjerovnika) protiv rješenja o odbijanju ovrhe ipak dopusti ovrha na nekretnini. ${ }^{39}$ Ako se po žalbi usvoji prijedlog za ovrhu, sud će po službenoj dužnosti narediti da se na onome mjestu u prvenstvenom redu na kojem je bila upisana zabilježba odbijanja

35 Tako Pezo, I., op. cit., str. 92-93.

36 Tako Ernst, H., op. cit., str. 405.

37 Zabilježbu bi mogla zahtijevati i osoba čiji je prijedlog za ovrhu na nekretnini odbijen.

38 Tako Bugarin, B., op. cit., str. 70.

39 Vidi Josipović, T., Zemljišnoknjižno pravo, str. 220. 
ovrhe upiše zabilježba ovrhe. Ovu zabilježbu sud briše po službenoj dužnosti ako rješenje o odbijanju ovrhe postane pravomoćno, odnosno kad umjesto te zabilježbe bude zabilježeno rješenje o ovrsi s tim prvenstvenim redom. ${ }^{40}$

Zabilježba dosude nekretnine još je jedna od zabilježba koja je neposredno povezana s ovršnim postupkom. Njome se štiti kupac nekretnine, a svi upisi prava na nekretnini koji su predloženi nakon zabilježbe dosude brišu se na prijedlog kupca uz uvjet pravomoćnosti rješenja o dosudi nekretnine. Pravni učinci zabilježbe dosude važni su, osim za publiciranje činjenice da je provedena dražba i da je nekretnina dosuđena određenoj osobi, i za osiguranje prava osobe kojoj je nekretnina dosuđena ako nakon provedene dražbe ovršenik raspolaže nekretninom. Zabilježbom dosude (čl. 89. ZZK-a) upisuje se u zemljišnu knjigu da je ovršni sud u postupku ovrhe na nekretnini donio rješenje o dosudi nekretnine osobi koja je na usmenoj javnoj dražbi ponudila najveću cijenu za nekretninu, odnosno koja je nekretninu kupila neposrednom pogodbom kad se na taj način može prodati nekretnina u ovršnom postupku (čl. 98., 99. OZ-a). ${ }^{41}$ Tu će zabilježbu po službenoj dužnosti narediti ovršni sud pri donošenju rješenja o dosudi nekretnine kupcu, a ona se može provesti i na prijedlog kupca u čiju je korist doneseno rješenje o dosudi. ${ }^{42}$ Zabilježba se upisuje u vlastovnicu na temelju rješenja o dosudi. Zabilježba će se brisati po dostavljanju pravomoćnog rješenja o dosudi s potvrdom ovršnog suda da je kupac položio kupovninu u skladu s tim rješenjem, a istodobno s upisom kupčeva prava vlasništva, ili po dostavi pravomoćnog rješenja kojim je dosuda, odnosno dražba ili prodaja oglašena nevažećom. ${ }^{43}$

Nekretnina se može prodati i neposrednom pogodbom ako se, najkasnije do prodaje na javnoj dražbi, o tomu sporazume stranke, hipotekarni vjerovnici i nositelji osobnih služnosti i stvarnih tereta koji prestaju prodajom nekretnine te odrede rok u kojem će se nekretnina prodati i osobu preko koje će se obaviti prodaja. Po zaključenju dražbe, a nakon što utvrdi tko je ponudio najveću cijenu i ispunio uvjete za dosudu, sud donosi rješenje o dosudi u kojem će odrediti brisanje prava i tereta na nekretnini, osim

40 Tako Pezo I., op. cit., str. 60.

41 Iz odredbe čl. 89. ZZK-a ne proizlazi precizno koji bi bio sadržaj upisa ove zabilježbe, pa tako imamo slučajeve da zk. sud kao sadržaj zabilježbe dosude obuhvati i oznaku ovršnog predmeta (najčešće bez naznake suda koji vodi ovršni postupak) i naziv kupca, ali češće samo jednostavno navede kako se „zabilježuje dosuda”. Takav upis ionako nema nikakav realni publicitetni učinak u odnosu na stvarnog kupca nekretnine pa bi ga čak bilo moguće održati i u slučaju oglašavanja dosude nevažećom i dosuđivanja nekretnine sljedećem kupcu po visini ponuđene cijene. Tako Bugarin, B., op. cit., str. 72.

42 Zabilježbu dosude nekretnine naređuje po službenoj dužnosti sud, koji je u ovršnom postupku donio odluku o tome tko je kupac nekretnine na javnoj dražbi prije pravomoćnosti rješenja o dosudi. U tom je smislu presuđeno: "Posebni propis iz odredbe čl. 89. st. 1. Zakona o zemljišnim knjigama ovlašćuje sud da po službenoj dužnosti naredi zabilježbu nekretnine u zemljišnoj knjizi nakon donošenja rješenja o dosudi, a ne tek nakon što takovo rješenje postane pravomoćno. Pravomoćnost rješenja o dosudi dakle nije pretpostavka za provođenje zabilježbe na temelju odredbe iz čl. 89. st. 1. Zakona o zemljišnim knjigama, koju je sud prvog stupnja pravilno primijenio."

Županijski sud u Bjelovaru, Gž-2183/00-2, od 30. XI. 2000.

43 Na prijedlog će se izbrisati i svi upisi koji su bili provedeni protiv dotadašnjeg vlasnika nakon upisa ove zabilježbe, kao i svi daljnji upisi koji su učinjeni s obzirom na njih. Tako Pezo, I., op. cit., str. 60 . 
onih koji ostaju i poslije predaje nekretnine ili koje je kupac preuzeo, te naložiti da se, nakon polaganja kupovnine i pravomoćnosti rješenja, u zemljišne knjige upiše pravo vlasništva kupca, odnosno da će se nekretnina dosuditi kupcima koji su ponudili nižu cijenu (redom prema veličini cijene), ako kupovnina ne bude položena u određenom roku (donošenjem posebnog rješenja i oglašavanjem ranije dosude nevažećom). ${ }^{44}$

Nakon pravomoćnosti rješenja o dosudi nekretnine i nakon što kupac položi kupovninu, donosi se zaključak o predaji nekretnine kupcu. Ovršni sud, po službenoj dužnosti, pri donošenju rješenja o dosudi mora naložiti zabilježbu dosude u zemljišnoj knjizi. $^{45}$

\section{LITERATURA}

1. Barjaktar, Biljana, Dopuštenost žalbe protiv rješenja zemljišnoknjižnog suda o upisu zabilježbe ovrhe, Informator, 5377/2005., str. 8-13.

2. Bugarin, Bojan, Ovrha na nekretninama i zemljišne knjige: ovršni zemljišnoknjižni upisi, Hrvatska pravna revija, 1/2015., str. 68-69.

3. Čizmić, Jozo, Šago, Dinka, Kačer, Blanka, Osnove zemljišnoknjižnog prava, Maribor, University of Maribor Press, 2018.

4. Dika, Mihajlo, Građansko ovršno pravo, Opće građansko ovršno pravo, Zagreb, Narodne novine, 2007.

5. Dika, Mihajlo, Sudsko i javnobilježničko založnopravno osiguranje tražbina na temelju sporazuma stranaka, u: Barbić, Jakša i dr., Zagreb, Novo ovršno i stečajno pravo, 1996.

6. Ernst, Hano, Zabilježba zabrane otuđenja ili opterećenja nekretnine na temelju pravnog posla, Aktualnosti hrvatskog zakonodavstva i pravne prakse, Aktualnosti hrvatskog

44 Vidjeti Hrvatin, B., Novote u ovršnom postupku, u Aktualnosti hrvatskog zakonodavstva i pravne prakse, Zagreb, Organizator, 2005., str. 348.

45 Namirenju vjerovnika pristupa se na ročištu za diobu kupovnine. Rješenjem o namirenju odlučit će se o namirenju ovrhovoditelja i drugih osoba kojima pripada pravo na namirenje (vodeći računa o prvenstvu i redoslijedu namirenja): hipotekarnih vjerovnika i kad nisu prijavili tražbine, nositelja osobnih služnosti i drugih prava koja prestaju prodajom te Republike Hrvatske, općina, gradova i županija po osnovi poreza i drugih pristojbi. Iz iznosa dobivenoga prodajom namiruju se prema načelu realnog prioriteta: u prvom isplatnom redu troškovi ovršnoga postupka, u drugom porezi i druge pristojbe dospjele za posljednju godinu, (ako su prijavljeni najkasnije na ročištu za diobu i dokazivi ovršnom ispravom), u trećem tražbine osigurane hipotekom, tražbine ovrhovoditelja koji je pokrenuo ovrhu, naknade za osobne služnosti i druga prava koje prestaju prodajom, nadhipoteke i druga prava koja su teret prava koja se namiruju (troškovi i kamate za posljednje tri godine od donošenja rješenja o dosudi određeni ovršnom ispravom namiruju se kao i glavna tražbina), i to ako iznos kupovnine dostaje za namirenje svih tražbina istodobno, a u protivnom razmjerno svojoj visini; u četvrtom troškovi ovršnog postupka osim onih navedenih u čl. 106. st. 1. t. 1. OZ, a posljednja dva reda po načelu vremenskog prioriteta. $\mathrm{U}$ peti isplatni red po redoslijedu namirenja dolaze tražbine navedene u čl. 106. st. 1. t. 2. $\mathrm{OZ}$ za vrijeme za koje se ne namiruju prema odredbama toga članka. Prodajom nekretnine ovršenik gubi pravo na posjed nekretnine i dužan ju je predati kupcu odmah nakon dostave zaključka o predaji nekretnine kupcu, odnosno i prije, ali u tom slučaju ovrhovoditelj mora položiti jamčevinu za štetu koja bi ovršeniku mogla biti prouzročena nedopuštenom prodajom ili obustavom ovrhe iz razloga za koje je ovrhovoditelj odgovoran. Nakon što donese zaključak o predaji nekretnine kupcu, sud će, na prijedlog kupca pristupiti ovrsi radi ispražnjenja i predaje nekretnine kupcu. Ovrha se provodi po pravilima o ovrsi ispražnjenjem i predajom nekretnine. Tako Mihelčić, G., op. cit., str. 31. 
zakonodavstva i pravne prakse, Godišnjak, 11/2004., str. 403-416.

7. Hrvatin, Branko, Novote u ovršnom postupku, Aktualnosti hrvatskog zakonodavstva i pravne prakse, Godišnjak, 12/2005, str. 313-366.

8. Josipović, Tatjana, Komentar Zakona o zemljišnim knjigama, Zagreb, Informator, 1998.

9. Josipović, Tatjana, Uloga zemljišnih knjiga u pravnom prometu nekretnina, HGK, Sektor za trgovinu, Šesti forum hrvatskih posrednika u prometu nekretninama, www.agenti.hr, str. 31-61.

10. Josipović, Tatjana, Zemljišnoknjižno pravo, Zagreb, Informator, 2001.

11. Kontrec, Damir, Bulka, Zinka, Aktualna pitanja zemljišnoknjižnog prava - edukacija za zemljišnoknjižne referente, Zagreb, Pravosudna akademija, 2016., str. 1-41.

12. Kontrec, Damir, Ovrha na nekretnini, Zbornik radova sa 23. foruma poslovanja nekretninama, Hrvatska gospodarska komora - sektor za trgovinu, str. 1-22 na https:// www.hgk.hr/zbornik-radova-sa-23-foruma-poslovanja-nekretninama.

13. Mihelčić, Gabrijela, Prisilno sudsko hipotekarno osiguranje tražbine, Zbornik Pravnog fakulteta Sveučilišta u Rijeci, vol. 28, 1/2007, str. 1-35.

14. Mihelčić, Gabrijela, u suradnji s Damirom Kontrecom, Komentar Ovršnog zakona s opsežnom sudskom praksom i abecednim kazalom pojmova, Zagreb, Organizator, 2015.

15. Milaković, Goran, Provedba upisa u zemljišne knjige nakon upisane zabilježbe ovrhe, Hrvatska pravna revija, 3/2007, str. 69-74.

16. Ovršni zakon, Narodne novine, br. 112/12, 25/13, 93/14, 55/16, 73/17.

17. Pezo, Ivica, Upisi u zemljišnu knjigu, vrste upisa, pravni temelj, učinci... prateći propisi, Zagreb, Novi informator, 2011.

18. Šago, Dinka, Provedba i učinci zabilježbe spora u zemljišnim knjigama u zakonodavstvu Republike Hrvatske, Revija za pravo i ekonomiju, Mostar, god. 18., 1/2017, str. 163-182.

19. Šago, Dinka, Zabilježba prvenstvenog reda u zemljišnim knjigama, Zbornik radova $s$ III. međunarodnog savjetovanja „Aktualnosti građanskog procesnog prava - nacionalna i usporedna pravnoteorijska i praktična dostignuća“, ur. Dinka Šago i dr., Sveučilište u Splitu, Pravni fakultet, 2017., str. 275-297.

20. Zakon o vlasništvu i drugim stvarnim pravima, Narodne novine, 91/1996, 68/1998, 137/1999, 22/2000, 73/2000, 114/2001, 79/2006, 141/2006, 146/2008, 38/2009, 153/2009, 90/2010, 143/2012, 152/2014.

21. Zakon o zemljišnim knjigama, Narodne novine, br. 91/96., 68/98., 137/99 - Odluka Ustavnog suda broj U-I-58/1997., U-I-235/1997., U-I-237/1997., U-I-1053/1997., U-I1054/1997. od 17. studenoga 1999., 114/01., 100/04., 107/07., 152/08. i 126/10., 55/13., $60 / 13,108 / 17$. 


\section{Dinka Šago*}

Summary

\section{RECORDATION PROVIDED BY ENFORCEMENT RULES AND INSURANCE REGULATIONS}

The topic of this paper is recordation intended to protect trust in land registers, with special reference to recordation provided by enforcement rules and insurance regulations. In this paper the focus is on a detailed description of recordation related to enforcement proceedings and the Enforcement Act. The importance of recordation as one of the entries in the land register, as well as the method and assumptions of recordation entry in the land register have been described. Recordation of initiating proceedings fills in a gap that occurs from the time of submission of the proposal to institute enforcement proceedings and recordation of enforcement. Recordation of enforcement is the first of recordations that are associated with enforcement proceedings. The effects of the recordation of enforcement, which is very important in order to preserve the rights of the execution creditor, i.e. the possibility of settlement the execution creditor, and thus the publication of the course of enforcement proceedings for a particular real estate, have been elaborated in the paper. The recordation of enforcement is also one of the recordations provided by the Enforcement Act. It protects the execution creditor, or the applicant for measures after the maturity of a claim. As part of the recordation of enforcement, the institute of forced establishment of lien on the real estate in order to ensure the claim has been treated as well.

Keywords: recordation; land registers; Enforcement Act.

\section{Zussamenfassung}

\section{VORMERKUNGEN DER RECHTSTATSACHEN LAUT ZWANGSVOLLSTRECKUNGSGESETZ}

Dieser Beitrag thematisiert die Vormerkung und den damit verbundenen Schutz des Vertrauens in das Grundbuch mit besonderer Berücksichtigung der durch Zwangsvollstreckungs- und Sicherungsregeln vorgesehenen Vormerkungen. Die mit dem Zwangsvollstreckungsverfahren verbundenen Vormerkungen müssen keinesfalls ausschließlich mit dem Zwangsvollstreckungsgesetz verbunden sein. Die Vormerkung derEinleitungdesZwangsvollstreckungsverfahrens fülltdieLücke, dieabdemZeitpunkt

* Dinka Šago, Ph.D., Assistant Professor, Faculty of Law, University of Split; dinka.sago@, pravri.hr. 
der Stellung des Antrags auf die Einleitung des Zwangsvollstreckungsverfahrens bis zu dem Zeitpunkt der Eintragung der Vormerkung der Zwangsvollstreckung entsteht. Die Vormerkung der Zwangsvollstreckung ist die erste Vormerkung, die mit dem Zwangsvollstreckungsverfahren verbunden ist. Der Beitrag bearbeitet die Auswirkungen der Vormerkung der Zwangsvollstreckung, die sehr wichtig für die Bewahrung der Rechte des Vollstreckungsgläubigers, beziehungsweise für die Befriedigung des Vollstreckungsgläubigers, sowie auch für die Bekanntgabe des Zwangsvollstreckungsverfahrens bezüglich einer Immobilie ist. Die Vormerkung der Durchsetzbarkeit ist auch eine der durch das Zwangsvollstreckungsgesetz vorgesehene Vormerkungen. Ihr Ziel ist, den Vollstreckungsgläubiger (der die Sicherung vorschlägt) nach der Fälligkeit der Forderung zu schützen. In diesem Rahmen wird auch das Rechtsinstitut des Zwangspfandrechts auf der Immobilie wegen der Forderungssicherung bearbeitet.

Schlüsselwörter: Vormerkung; Grundbücher; Zwangsvollstreckungsgesetz.

\author{
Riassunto
}

\title{
LE ANNOTAZIONI DI CIRCOSTANZE GIURIDICHE NELLA LEGGE SULL'ESECUZIONE
}

Oggetto del presente lavoro è l'annotazione al fine della tutela dell'affidamento nei libri fondiari con particolare attenzione per le annotazioni previste dalle norme sull'esecuzione e dalle regole in materia di assicurazione. Le annotazioni che sono connesse al procedimento esecutivo non debbono necessariamente essere legate alla sola legge sull'esecuzione. L'annotazione dell'attivazione del procedimento colma la lacuna che si manifesta nell'intervallo di tempo tra l'attivazione del procedimento esecutivo e l'annotazione dell'esecuzione. L'annotazione dell'esecuzione è la prima tra le annotazioni che si collega al procedimento esecutivo. Si disaminano pertanto gli effetti dell'annotazione che è davvero importante al fine della garanzia del diritto del creditore, ossia al fine del suo soddisfacimento, come pure al fine di dare pubblicità al fatto che un determinato immobile è sottoposto ad una procedura esecutiva. L'annotazione di esecutività è altresì una delle annotazioni previste con la legge sull'esecuzione. Con essa si tutela l'esecutore, ovvero il garante dopo la scadenza del credito. Nel contesto dell'annotazione dell'esecutività viene esaminato anche l'istituto della costituzione forzata del diritto di garanzia su bene immobile al fine di assicurare il credito.

Parole chiave: annotazione; libri fondiari; legge sull'esecuzione. 